International Journal of Advanced Academic Studies 2020; 2(3): 200-203

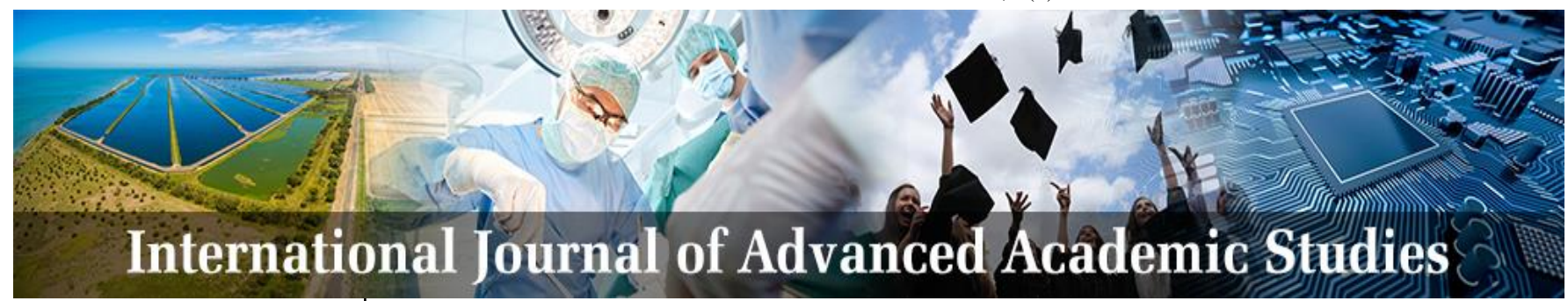

E-ISSN: 2706-8927

P-ISSN: 2706-8919

www.allstudyjournal.com IJAAS 2020; 2(3): 200-203

Received: 17-03-2020

Accepted: 21-04-2020

Sohaillah Fazel Faizi

Kabul Education University, Faculty of Languages and

Literature English department

Kabul, Afghanistan
Corresponding Author: Sohaillah Fazel Faizi

Kabul Education University, Faculty of Languages and Literature English department Kabul, Afghanistan

\section{Using Technology as a Resource to Enhance Teaching \& Learning}

\section{Sohaillah Fazel Faizi}

DOI: https://doi.org/10.33545/27068919.2020.v2.i3c.150

\begin{abstract}
This article attempts to explore the technological resources that can motivate students to enhance their learning process. The aim of this study is to increase the realization of instructors regarding the importance of Educational technologies integrated in teaching and learning, also the factor that effect and influence their plans to empower their teaching with the usage of technology and the challenges they would face in classes. It is very important for university students and lecturers to know the challenges that they have encountered in their academic life and try to find a solution for them. When they are going to produce or generate something new in their second language learning they should try not to make those challenges again. Technological instruments which motivate students in second language learning are highly recommended to use in teaching in order to enhance students learning in classroom. To enhance students learning in and out of the class instructors can integrate many kinds of technological instruments in their teaching.
\end{abstract}

Keywords: indexed terms-technology teaching learning students instructors

\section{Introduction}

Students are happy that they live in the age of technology. Today students use technology on a daily basis, especially during the pandemic. Students' online studies include getting lessons through google class, and zoom meetings. They change their system of learning and studying like texting, social networking, and web surfing. Today technology became more useful and more enjoyable for most of the Students. Hall and Khan (2003) [7] described that implementing technology for specific purposes as a regular procedure which empowers uncertain gainers to prosperously assume to apply technology. To use different kinds of technology in class students will involve in arrangement of decision which are the outcomes of advantages and disadvantages. Learning technologies in higher education advancement very fast, which is credited to the realization that teaching could be innovative by the support of learning technologies (Fernandez-Ferrer \& Cano, 2016) ${ }^{[6]}$. The assessment forms enhanced variously (Farrell \& Rushby 2016) ${ }^{[5]}$ with the help of learning technologies. Drent and Meelissen (2008) ${ }^{[3]}$ argued that the teaching which is integrated with modern technology will bring benefits to the learners, like enabling them to develop skills like searching, collaboration, communication, assessing information and solving problems. Technology have also developed the chance of best teaching like providing skillful improvement. Karasavvidis and Kollias (2014) ${ }^{[9]}$ argued that researches on using technology in teaching has failed in the three past decades in changing the system of technology and training application. They also reported that there are couple of main argue about the fail of implementing technology in trainings. Number one is a minimal technology practice during teaching. Second, although academics accept technology, it develops in a way which fortify the case - que rather than bringing innovation in teaching. The relation among technology and learning has different dimensions but students learning can improve by using a particular technology (Moeller \& Reitzes, 2011) ${ }^{[11]}$. University instructors will agree with the diversity abilities of students, success, attaining methods and also arranging both learners and professors superior interest in many ways of learning by integrating technology in teaching (Massy \& Zemsky, 1995) ${ }^{[12]}$. Technology changes the environment of the classroom in to a collaborative learning, it also is an influential contributor to learning when using in class to extend students engagement in expressive knowledgeable and reliable curriculum. Technology is a best tool for students learning especially for learning English language when 
the teachers use technology in teaching he/she is modeling the usage of technology, students comprehend proper consumption of technology then get advantage from acquaintance and will use independently in their lessens. Even weak students will participate effectively in class and feel self-confidence when using technology in teaching to support the curriculum (DePasquale, McNamara, \& Murphy, 2003) ${ }^{[4]}$. Researches have shown that using technology in classroom instruction has many advantages like engaging students to critical thinking and problem dissolve by using technology as tool for launching significant project. Using Technology can encourage the development skills of having better and higher thinking. (Kurt, 2010) ${ }^{[10]}$. According to Keser, Huseyin, \& Ozdamli (2011) ${ }^{[13]}$ learners acquire effectively by reading the work of each other's, and their spelling, vocabulary, and structuring sentence and editing using computer will increase. Lin \& Yang (2011) [17] argued that students' contribution in lessons using computer help them to comprehend the teacher speaking about lesson. Enduring or ongoing use of computer as technology tool advance and change the way of live for the societies and their efforts. The World Wide Web is another effective tool which is very important for students learning (Açıkalın, 2009) ${ }^{[1]}$. It means to arrange a vital knowledge to learners. There are numerous ways for teachers to practice technology to increase learners' knowledge. Developing plus Integrating projector, computer, and internet beacon part of people daily life. Therefore, using technology for active and stable learning in $21^{\text {st }}$ century act as an extreme vehicle. Students can access resources online whenever they need to, and instructors can see which students might need extra help.

Using technology for getting data from different electronic books and academic journals for teaching and learning have many advantages such as: It increases students' interaction, even dull students will participate in the class that will help them to remember new and additional information. On the other hand, students will become autonomous by discussing the information in the class by developing the discussion which surround details. Consequently, they will enhance their skills, and simply develop their new students- based informative materials (Tutkun, 2011) ${ }^{[23]}$. Learners trust on technology integration in teaching and curriculum, they claim that they can participate actively in class activity they can learn the lesson easily by using technology as a fun. They believe that using technology in teaching make the lessons amusing, collaborating, pleasant, and adaptable. When students learn the lesson, they start invention (Baytak, Tarman, \& Ayas, 2011) ${ }^{[2]}$. It provides students chances to cooperate with their peers which result in learning from each other. Integrating technology to teaching and learning more involved; therefore learners mostly keep more dates. Integrating the new equipment in teaching will change class into an active and participative class in which learners are motivated enough to use technology in their daily basis and became a good social interactor, increase their information and would have a positive outcome, also qualified of opening ways of learning. Teacher can bring changes in their methods of teaching and on their students by giving homework to do it online and submit their work online too. They can also inspire them to use electronic books to find out updated data for their homework that the teachers assign. Students better learn with technology. Twenty first century students and new generation are habituated with new technology for example: They are reading visual images, and they have the ability of fast response. However there are some concerns for using technology all the time like they have very short attention time, lack of text literacy, they do not have reflection poorly working tools. Instead the new generation are studying in group or peer work, and they are mostly engaged with experiences. The students can learn individually by starting and ongoing working and make relationship and contacting with all their peers. Another benefit of integrating technology is that when instructors give homework to Students they become very happy to receive immediate feedback from their professors. Worldwide objective is education in high quality.

Pelgrum (2001) [20], stated that modernization and achievements are mostly reliant on talent and awareness of professors. Learning technology grant chances of invention on students'. However there are some obstacles to impressive integration of educational technology like shortage of awareness and talent, insufficient sources and administration help from institution. Internet is another barrier for students learning process, if they use internet in better way to increase their knowledge.

According to Toffler (1984) ${ }^{[13]}$, the body is the creative use of change to guide change itself, which can be saved from the shock of the future and achieve a better and more humane future. On the other hand, the basis for change is the willingness and interest to accept. It is, otherwise, change does not necessarily happen, it does not have the expected results, and it is always accompanied by resistance and defensiveness of people. Another important point that should be considered in this regard is to know that basically any technology and technology is a tool and the efficient use of any kind of technology originates from deep thought, culture and social relations, therefore, in order to use information technology effectively and efficiently, especially in the development of education, it is necessary to improve approaches, review educational policies, reorganize the content, improve the human resources, design and effective curriculum and change the cultural criteria to provide. We coexist with twin technology.

Finally, the application of new technology in our education system increases the hope of classroom efficiency and makes it possible for students to learn continuously and to learn both formally and informally outside the classroom. Therefore, it is necessary to provide the necessary coordination and adequate arrangements in this regard, I create the ground for the benefit of our country's education system from the benefits of such new technologies.

We live in a world which technology is the most important part of it. Today most of the jobs which do not involved with technology in the past now they use technology. In the past two decades not only youths but even small kids and infants also start using technology on their daily lives like mothers start calming and making busy their infants by showing them the colorful pictures playing songs for them and they start working with smart phones, Tablet, high pad and they learn how to click on the screen and calling their fathers, mostly Technogym is used by children now a days for playing games which encourage their minds for thinking and school students use technology for texting, chatting, playing and doing their home works. Human become addicted with integration of many kind of 
technology in their lives in money ways. The century which we live is $21^{\text {st }}$ century, Educational technologies have gradually develop. Higher education Institutions gradually turned the ancient system with integrating technology to teaching and focus on raising student's achievement in our country. University instructors and policy makers increased their commitments to bring changes on their curriculum and instructional practice to get the maximum effects of the student's outcome. The instructors discovered new ways of offering tough theories clear in the class by the help of Technology. Making Power Point presentation which could be both audio and visual help learners to comprehend the new knowledge and will practices it in their daily lives. when using Technology with teaching; not only in our country but globally students retain more information and provides meaningful learning experiences, Technology will provide learners chances for cooperation to their colleagues cause understanding from each other. The other aim of integrating technology in teaching is to advance students creativity, to become ready for their future jobs, Today not only student work with technology but even illiterate labors also use Technology for communication, calculation, making films, photography and many more.

This article attempts to explore the technological resources that can motivate students to enhance their learning process. The purpose of this study was to gain a better understanding of lecturers' perceptions of the value of learning technologies and factors likely to influence their decisions to adopt and integrate these technologies into teaching. The research also aimed to identify opportunities afforded by these technologies in enhancing student learning, as well as possible adoption challenges. Determine the impact of educational technology in teaching learning process. Assess the status of educational technology in teaching learning process. To find out the most common tools for teaching to enhance students learning in the region.

\section{Methodology}

The researcher reviewed a number of studies which were downloaded from some well-known databases. The researcher served and searched the research papers related to integrating technology in teaching process and practice learning. The purpose of this study is to find out the sources of technology to motivate students to learn the lessons, and also find out the effective ways of integrating technology in teaching in order to enhance students learning process. The purpose of this study was to gain a better understanding of lecturers' perceptions of the value of learning technologies and factors likely to influence their decisions to adopt and integrate these technologies into teaching. The research also aimed to identify opportunities afforded by these technologies in enhancing student learning, as well as possible adoption challenges. Determine the impact of educational technology in teaching learning process. Assess the status of educational technology in teaching learning process. To find out the most common tools for teaching to enhance students learning in the region.

\section{Discussion}

The overall, results suggested that students value the influence of integrated technology in teaching which has enhanced their learning process. There are some issues that motivated quick implementation technology integration in teaching and learning. As Pelgrum (2001) ${ }^{[20]}$ stated that skills and knowledge of educators depend on the success of any modernization. Further, Buabeng-Andoh (2012b) [6] mentioned that teachers support, attitude and believes depend on the success of every educational technology program in any institution, and the capabilities of a certain technology like computer, projector and LCD will transfer the new knowledge which is part of curriculum by the usage of these technology and enhanced students learning. Practicing educational technology considerably help teaching effectiveness. Students Commitment recommends better chance for them to confirm their views in literature, proposing that for higher order thinking and communicating skills students develop their invention and improve reasoning skills, communicating skills, and other higher skills such as critical thinking (Chigona \& Chigona, 2010; Trucano, 2005) ${ }^{[8,24]}$. Instructors that used learning technology already or currently in their teaching they use these technologies to encourage students and simplify their learning to meet the objective and implement academic responsibilities. Instructors Valued students learning by the contribution of technology. Student's tendency and understanding recommend the effectiveness of using technology in teaching which are the key factors and essential in assistant of The Teaching. Attitude is determining as an important coefficient of technology admition as a key factor in technology implementation (Shiue, 2007; Teo, 2008, 2012; Taylor \& Todd, 1995) ${ }^{[21]}$. Moreover, attitude, behavioral has controlled, self-efficacy and observed practicality which targeted integrating technology as important elements of teaching and learning. Moreover the connected issues like easiness of integrating knowledge and confidence in handling technologies were also viewed important. Similar to previous work, analysis of the data revealed that majority of respondents believed that the use of technology in teaching was within their control, these results are in line with the literature (Ajzen \& Madden 1985) ${ }^{[4]}$. Integration of technology in teaching has changed student's high level of self-efficacy, and assist them to solve the challenges that will face in their daily life. Though the modern technology like the updated technology infiltrate academic landscape, effective integration needs many instructors to acquaint themselves with different kinds of technologies, to advance confidence.

\section{Conclusion}

To conclude the advantages of integrating technology in teaching and learning are countless. As far as we know, technology integration brought us the following benefits. Technology has increased student collaboration; it also increased knowledge and build students' skills, motivation and engagement in lessons. Integration of technology in teaching has changed student's high level of self-efficacy, and assist them to solve the challenges that will face in their daily life. Using or integrating technology in teaching and learning have a positive effect on both teachers and students. Technological tools like LCD, projector, smart phone, computer, and tablet has increased students abilities of reading, typing, researching and studying online courses or getting their M.A, B,A and many more. Educational technology has a positive effect on students learning and outcome. Technology integration has helped disable students and students with special learning needs. Integrating Technology in teaching and learning enable and 
encouraged even dull student to participate in class activities and increased self- confidence in students too. Learners price technology integration in their teaching. Educators pointed that using technology will increase their creativity in classes. Having access to various kinds of technology in or out of the class can ease students learning.

\section{References}

1. Açıkalın M. Pre-service elementary teachers beliefs about use of the internet in the social studies classroom. European journal of teacher education. 2009; 32(3):305-320.

Doi: 10.1080/02619760802553030. Alvin

2. Ajzen I, Madden TJ. Prediction of goal directed behavior: attitudes, intentions and perceived behavioral control. Journal of Experimental Social Psychology. 1986; 22:453-474.

3. Bagozzi RP. Attitudes, intentions and behavior: A test of some key hypothesis. Journal of Personality and Social Psychology. 1981; 41:607-627.

4. Ajzen Madden. From intentions to actions: A theory of planned behavior. In Action control. Springer Berlin Heidelberg, 1985, 11-39.

5. Baytak A, Tarman B, Ayas C. Experiencing technology integration in education: children's perceptions. International Electronic Journal of Elementary Education B. Tyler personal communication. 2011-2014; 3(2):139-151.

6. Buabeng-Andoh C. Factors influencing teachers' adoption and integration of information and communication technology into teaching: A review of the literature. International Journal of Education and Development using Information and Communication Technology. 2012b; 8(1):136-155.

7. Drent M, Meelissen M. Which factors obstruct or stimulate teacher educators to use ICT innovatively? Computers \& Education. 2008; 51(1):187-199.

8. Chigona A, Chigona W. An investigation of factors affecting the use of ICT for teaching in Western Cape Town, the 18th European Conference on Information System ECIS 2010 proceedings, Paper 6, 2010.

9. DePasquale R, McNamara E, Murphy K. Meaningful connections: Using technology in primary classrooms. Young Children on the Web, Retrieved from, 2003. http://journal.naeyc.org/btj/200311/techinprimaryclassr ooms.pdf

10. Farrell T, Rushby N. Assessment and learning technologies: An overview. British Journal of Educational Technology. 2016-2015; 47(1):106-120. doi:10.1111/bjet.12348

11. Fernández-Ferrer M, Cano E. The influence of the internet for pedagogical innovation: using twitter to promote online collaborative learning. International Journal of Educational Technology in Higher Education, 2016, 13(22). doi:10.1186/s41239-0160021-2.

12. Hall BH, Khan B. Adoption of new technology (No. w9730). National Bureau of Economic Research. Retrieved on 10 September 2016 from, 2003. http://www.nber.org/papers/w9730.

13. Huseyin, Ozdamli. Effects of training on cloud computing services on M-learning perceptions and adequacies Procedia-Social and Behavioral Sciences. 2011; 116(21):5115-5119.
14. Keser H, Uzunboylu H, Ozdamli F. The trends in technology supported collaborative learning studies in 21 st century. World journal on educational technology. 2012; 3(2):103-119.

15. Karasavvidis I, Kollias V. Technology integration in the most favorable conditions: findings from a professional development training program. In C. Karagiannidis (Ed.), Research on e-learning and ICT in education, 2014, 197-224. New York: Springer.

16. Kurt S. Technology use in elementary education in Turkey: A case study. New Horizons in Education. 2010; 58(1):65-76.

17. Lin, Yang. J Chen, L Yang, Y Zhang, M Alber, DZ ChenAdvances in neural information processing systems, 2011, 3036-3044.

18. Moeller B, Reitzes T. Integrating technology with student-centered learning. A report to the Nellie Mae education foundation. Retrieved from, 2011. http://www.nmefoundation.org/getmedia/befa9751d8ad-47e9-949d-bd649f7c0044/integrating.

19. Massy WF, Zemsky R. Using information technology to enhance academic productivity. Washington, DC: Interuniversity Communications Council, Inc., 1995.

20. Pelgrum WJ. Obstacles to the integration of ICT in education: Results from a worldwide educational assessment. Computers and Education. 2001; 37:163178.

21. Shiue, 2007; Teo, 2008, 2012; Taylor \& Todd, 1995. Taylor S, Todd P. Decomposition and crossover effects in the theory of planned behavior: a study of consumer adoption intentions. International Journal of Research in Marketing. 1995; 12(2):137-155.

22. Toffler A. Future Shock Amazon printing preass. Washengton DC Copyright (C) 1970 by Alvin Toffler, 1984.

23. Tutkun O. Internet access, use and sharing levels among students during the teachinglearning process. The Turkish Online Journal of Educational Technology, 2011, 10(3).

24. Trucano M. Quick guide: ICTs in education challenges and research questions. World Bank. Retrieved 21 February, 2005-2017, from http://www.infodev.org/articles/quick-guideictseducation-challenges-and-research-questions 